\title{
Type II cGMP-dependent protein kinase inhibits the migration, invasion and proliferation of several types of human cancer cells
}

\author{
MIN WU, YAN WU, HAI QIAN, YAN TAO, JI PANG, YING WANG and YONGCHANG CHEN \\ Department of Physiology, School of Medicine, Jiangsu University, Zhenjiang, Jiangsu 212013, P.R. China
}

Received November 15, 2016; Accepted June 28, 2017

DOI: $10.3892 / \mathrm{mmr} .2017 .7290$

\begin{abstract}
Previous studies have indicated that type II cyclic guanosine monophosphate (cGMP)-dependent protein kinase (PKG II) could inhibit the proliferation and migration of gastric cancer cells. However, the effects of PKG II on the biological functions of other types of cancer cells remain to be elucidated. Therefore, the aim of the present study was to investigate the effects of PKG II on cancer cells derived from various types of human tissues, including A549 lung, HepG2 hepatic, OS-RC-2 renal, SW480 colon cancer cells and U251 glioma cells. Cancer cells were infected with adenoviral constructs coding PKG II (Ad-PKG II) to up-regulate PKG II expression, and treated with 8-(4-chlorophenylthio) (8-pCPT)-cGMP to activate the kinase. A Cell Counting kit 8 assay was used to detect cell proliferation. Cell migration was measured using a Transwell assay, whereas a terminal deoxynucleotidyl transferase 2'-deoxyuridine, 5'-triphosphate nick-end labeling assay was used to detect cell apoptosis. A pull-down assay was used to investigate the activation of Ras-related C3 botulinum toxin substrate (Rac) 1 and western blotting was used to detect the expression of proteins of interest. The present results demonstrated that EGF (100 ng/ml, $24 \mathrm{~h})$ promoted the proliferation and migration of cancer cells, and it suppressed their apoptosis. In addition, treatment with EGF enhanced the activation of Rac1, and up-regulated the protein expression of proliferating cell nuclear antigen, matrix metalloproteinase (MMP)2, MMP7 and B-cell lymphoma (Bcl)-2, whereas it down-regulated the expression of Bcl-2-associated $\mathrm{X}$ protein. Transfection of cancer cells with Ad-PKG II, and PKG II activation with 8-pCPT-cGMP, was identified to counteract the effects triggered by EGF. The present results suggested that PKG II may exert inhibitory effects on the proliferation and migration of various types of cancer cells.
\end{abstract}

Correspondence to: Professor Yongchang Chen, Department of Physiology, School of Medicine, Jiangsu University, 301 Xuefu Road, Zhenjiang, Jiangsu 212013, P.R. China

E-mail: 1000007247@ujs.edu.cn

Key words: type II cyclic guanosine monophosphate-dependent protein kinase, proliferation, migration, apoptosis, multiple tissue cancer cells

\section{Introduction}

The 'hallmarks of cancer', as suggested by Hanahan and Weinberg (1), comprise 10 common biological traits shared by cancer cells, that are acquired during the tumor development process, including sustained proliferation, resistance to cell death, invasive and metastatic capabilities. Therefore, the development of therapeutic strategies targeting the aforementioned biological traits, and the associated gene expression and signaling pathways, is critical for the effective treatment of patients with cancer.

Cyclic guanosine monophosphate (cGMP)-dependent protein kinase type II (PKG II) is a structurally and functionally distinct membrane-bound enzyme. As a Ser/Thr kinase, PKG II has been reported to serve a role in intestinal secretion, bone growth, and learning and memory (2-4). In addition, previous studies have suggested that PKG II may be associated with tumor pathogenesis: PKG II has been reported to suppress cancer cell proliferation, including human colon and prostatic stromal cancer cells and glioma cells (5-7), and promote the apoptosis of breast cancer cells $(8,9)$. Preliminary research demonstrated that the expression and activity of PKG II appeared to be down-regulated in human gastric cancer cells compared with normal gastric mucosal cells (10). In addition, PKG II was demonstrated to inhibit the proliferation and migration, and enhance the apoptosis of gastric cancer cells (11-13). The molecular mechanisms underlying the effects of PKG II on cancer cells were also investigated: PKG II was observed to inhibit epidermal growth factor (EGF)-induced EGF receptor (EGFR) Tyr phosphorylation and activation, and to subsequently inhibit mitogen-activated protein kinase kinase (MAPK)/extracellular signal-regulated kinase (ERK), phospholipase (PL) $\mathrm{C} \gamma 1$ and phosphatidylinositol-4,5-bisphosphate 3-kinase (PI3K)/protein kinase B (Akt)-mediated signal transduction pathways, initiated by EGF/EGFR activation in gastric cancer cells (11-13). However, the putative anti-cancer effects of PKG II on other types of cancer cells, apart from gastric cancer cells, remain to be investigated. Therefore, the present study aimed to investigate the actions of PKG II in vitro on several types of cancer cells derived from various tissues, including human A549 lung, HepG2 hepatic, OS-RC-2 renal, SW480 colon cancer and U251 glioma cells. The effects of PKG II on the proliferation, migration and apoptosis of the aforementioned cells were investigated and the molecular mechanisms that were involved were explored. 


\section{Materials and methods}

Cell lines and reagents. Human lung cancer cell line A549, hepatic cancer cell line HepG2, renal cancer cell line OS-RC-2, colon cancer cell line SW480 and glioma cell line U251 were obtained from the Cell Bank of the Chinese Academy of Sciences (Shanghai, China). The cells were cultured in Dulbecco's modified Eagle's medium (DMEM), supplemented with $10 \%$ heat-inactivated fetal bovine serum (FBS; Gibco; Thermo Fisher Scientific, Inc., Waltham, MA, USA), $100 \mathrm{U} / \mathrm{ml}$ penicillin and $100 \mu \mathrm{g} / \mathrm{ml}$ streptomycin (HyClone; GE Healthcare Life Sciences, Logan, UT, USA), in a humidified incubator at $37^{\circ} \mathrm{C}$ and $5 \% \mathrm{CO}_{2}$. When cells grew to $\sim 80$ confluence they were sub-cultured. Adenoviral vectors encoding the cDNA of $\beta$-galactosidase (Ad-LacZ) and PKG II (Ad-PKG II) were kind gifts from Dr Gerry Boss and Dr Renate Pilz (Department of Medicine, University of California, San Diego, CA, USA). 8-(4-chlorophenylthio)-cGMP (8-pCPT-cGMP), a cell-permeable cGMP analog, was purchased from EMD Millipore (Billerica, MA, USA). Antibodies against PKG II (cat. no. sc-25430; dilution, 1:500), $\beta$-actin (cat. no. sc-4778; dilution, 1:1,000), Ras-related C3 botulinum toxin substrate (Rac) 1 (cat. no. sc-24567; dilution, 1:500) and proliferating cell nuclear antigen (PCNA; cat. no. sc-25280; dilution, 1:500) were obtained from Santa Cruz Biotechnology, Inc. (Dallas, TX, USA); antibodies against matrix metalloproteinase (MMP)2 (cat. no. BS1236; dilution, 1:500), MMP7 (cat. no. BS6059; dilution, 1:500), B-cell lymphoma (Bcl)-2 (cat. no. BS1511; dilution, 1:500) and Bcl-2-associated $\mathrm{X}$ protein (Bax; cat. no. BS2538; dilution, 1:500) were from Bioworld Technology, Inc. (St. Louis Park, MN, USA). Horseradish peroxidase (HRP)-conjugated goat anti rabbit and goat anti mouse secondary antibodies (cat. nos. 111-035-003 and 115-035-003; dilution, 1:10,000) were purchased from Jackson Immuno Research Laboratories, Inc. (West Grove, PA, USA). Cell Counting kit (CCK) 8 was from R\&S Biotechnology Co., Ltd. (Shanghai, China). Transwell inserts were purchased from Corning Incorporated (Corning, NY, USA). In situ Cell Death Detection kit used for the terminal deoxynucleotidyl transferase 2'-deoxyuridine, 5'-triphosphate nick-end labeling (TUNEL) assay was ordered from Roche Diagnostics GmbH (Mannheim, Germany). Enhanced chemiluminescence (ECL) reagents were from EMD Millipore.

CCK8 assay. Cells were seeded in 96-well plates at a density of $1 \times 10^{4}$ cells/well and cultured in DMEM at $37^{\circ} \mathrm{C}$ for $12 \mathrm{~h}$. Following attachment, cells were infected with $1 \times 10^{10} \mathrm{pfu} / \mathrm{ml}$ Ad-LacZ or Ad-PKG II for $24 \mathrm{~h}$ at $37^{\circ} \mathrm{C}$, serum-starved for $12 \mathrm{~h}$, and then treated with 8-pCPT-cGMP $(250 \mu \mathrm{M})$ for $1 \mathrm{~h}$, followed by treatment with EGF $(100 \mathrm{ng} / \mathrm{ml})$ for 12 or $24 \mathrm{~h}$. Subsequently, $\sim 10 \mu \mathrm{l}$ CCK8 solution was added to each well and incubated for $30 \mathrm{~min}$ at $37^{\circ} \mathrm{C}$. The optical density of each well at $450 \mathrm{~nm}$ was measured using a microplate reader. Data were presented as a percentage of the OD value of the control group. Experiments were performed in triplicate.

Cell migration assay. The migratory capabilities of cancer cells were assessed using a Transwell assay. Following trypsinization, $5 \times 10^{4}$ cells were seeded into the upper chambers of the Transwell inserts, which contained DMEM without FBS.
Cell migration to the lower membrane was induced by medium containing 10\% FBS in the lower chamber for $12-24 \mathrm{~h}$. The non-migrated cells in the upper chamber were carefully removed. Cells migrated to the lower membrane were fixed with $4 \%$ paraformaldehyde at $4^{\circ} \mathrm{C}$ for $30 \mathrm{~min}$, stained in $0.07 \%$ Giemsa solution for $10 \mathrm{~min}$ at room temperature, and rinsed in water. Stained cells were observed under a light microscope and counted in 5 randomly selected fields/insert. Experiments were performed in triplicate.

Detection of apoptosis using TUNEL assay. Cells were seeded in 24-well plates $\left(5 \times 10^{4}\right.$ cells/well), cultured in FBS-free DMEM and treated with Ad-PKG II, 8-pCPT-cGMP and EGF, as mentioned above. The cells were then fixed with $4 \%$ paraformaldehyde for $30 \mathrm{~min}$ at room temperature, washed three times with PBS, and then permeabilized with $1 \%$ Triton $\mathrm{X}-100$ for $4 \mathrm{~min}$ at $4^{\circ} \mathrm{C}$. Subsequently, $500 \mu \mathrm{l}$ terminal deoxynucleotidyl transferase (TdT)-labeled nucleotide mix was added to each well and the plate was kept at $37^{\circ} \mathrm{C}$ for $60 \mathrm{~min}$ in the dark. The wells were rinsed twice with PBS and then counterstained with $10 \mathrm{mg} / \mathrm{ml} \mathrm{4,6-diamidino-2-phenylindole}$ (OriGene Technologies, Inc., Beijing, China) for $5 \mathrm{~min}$ at $37^{\circ} \mathrm{C}$ washed with PBS and covered with coverslip. Apoptotic cells were characterized by a dark-brown staining of the nucleus and nuclear membrane. Quantification was performed by counting the number of positive cells in 4 randomly chosen fields within each x200 frame using an Olympus microscope (BX43, Olympus, Japan). Image-Pro Plus version 6.0 software (Media Cybernetics, Boston, MA, USA) was used to quantify the TUNEL-positive cells. Experiments were performed in triplicate.

Pull-down assay of active small $G$ protein Racl. The activity of Racl was assessed using a pull-down assay. Cells were infected with Ad-PKG II, treated with 8-pCPT-cGMP $(250 \mu \mathrm{M})$ for $1 \mathrm{~h}$ and with EGF $(100 \mathrm{ng} / \mathrm{ml})$ for $5 \mathrm{~min}$, and then lysed in lysis buffer (25 mM HEPES $\mathrm{pH} 7.5,150 \mathrm{mM}$ $\mathrm{NaCl}, 1 \%$ NP40, $10 \%$ glycerol, $25 \mathrm{mM} \mathrm{NaF}, 10 \mathrm{mM} \mathrm{MgCl}$, $0.25 \%$ sodium deoxycholate, $1 \mathrm{mM}$ EDTA, $1 \mathrm{mM} \mathrm{Na}_{3} \mathrm{VO}_{4}$, $10 \mathrm{mg} / \mathrm{ml}$ aprotinin and $10 \mathrm{mg} / \mathrm{ml}$ leupeptin) (14). The protein extracts were incubated with glutathione-Sepharose beads and glutathione S-transferase-Rac-RBD (GST-RBD) at $4^{\circ} \mathrm{C}$ for $1 \mathrm{~h}$. The activated Racl bound to the beads and total Racl in cell extracts was detected using western blot analysis with antibodies against Rac1. Experiments were performed in triplicate.

Western blot analysis. Cells were treated with Ad-PKGII, 8-pCPT-cGMP or EGF according to the different groups, and lysed in lysis buffer $(5 \% \beta$-mercaptoethanol, $1 \%$ bromophenol blue, $0.2 \%$ SDS, $25 \%$ glycerinum, $12.5 \% 0.5 \mathrm{M}$ Tris- $\mathrm{HCl}$ and $35.5 \% \mathrm{H}_{2} \mathrm{O}$ ) for $5 \mathrm{~min}$ at $100^{\circ} \mathrm{C}$. Proteins were quantified using a bicinchoninic acid protein assay kit (cat. no. P0009; Beyotime Institute of Biochemistry, Beijing, China). Equal quantities of protein $(40 \mu \mathrm{g})$ were separated by $10 \%$ SDS-PAGE, prior to transferring proteins onto polyvinylidene difluoride membranes (0.4 $\mu \mathrm{m}$; EMD Millipore, Billerica, MA, USA). The membranes were blocked in 5\% BSA in TBST $(0.1 \%$ Tween-20) for $1 \mathrm{~h}$ at $4^{\circ} \mathrm{C}$ and incubated with primary antibodies as stated in section of cell lines and reagents for $12 \mathrm{~h}$ at 
$4^{\circ} \mathrm{C}$, followed by incubation with the corresponding secondary antibodies as stated in section of cell lines and reagents for $1 \mathrm{~h}$ at room temperature, with 3 washes by TBST (0.1\% Tween-20) following each incubation. Protein bands were visualized using ECL reagents (EMD Millipore, Billerica, MA, USA) and analyzed by Tanon MP version 4.1.2 software (Tanon Science and Technology Co., Ltd., Shanghai, China).

Statistical analysis. All experiments were performed in triplicate. Data are expressed as the mean \pm standard deviation. One-way analysis of the variance and Fisher's least significant difference post hoc tests were performed to evaluate the differences among groups. Statistical analysis was performed using SPSS version 13.0 software (SPSS, Inc., Chicago, USA). $\mathrm{P}<0.05$ was considered to indicate a statistically significant difference.

\section{Results}

PKG II inhibits EGF induced-proliferation in cancer cells. The proliferative activity of various types of cancer cells was assessed using a CCK8 assay. The present results indicated that following EGF (100 ng/ml) stimulation for $24 \mathrm{~h}$, the numbers of living cells were increased by 1.89-, 1.22-, 1.53-, 1.68- and 1.51-fold in A549, HepG2, OS-RC-2, SW480 and U251 cells, respectively ( $\mathrm{P}<0.05$; Fig. 1). However, when cells were infected with Ad-PKG II to enhance PKG II expression, and subsequently stimulated with 8-pCPT-cGMP $(250 \mu \mathrm{M})$ for $1 \mathrm{~h}$ to activate the kinase, EGF treatment was demonstrated to have no effect on cellular proliferation (Fig. 1). These findings suggested that activated PKG II may inhibit the EGF-induced increase of proliferation in various types of cancer cell lines.

PKGII inhibits EGF-induced PCNA expression. The expression of PCNA, which is considered a direct and reliable indication of cell proliferation, was detected in cancer cells using western blot analysis (15). The present results demonstrated that across all 5 cancer cell lines, the protein expression of PCNA in EGF-treated cells was significantly increased compared with in untreated cells $(\mathrm{P}<0.05$; Fig. 2A-F). Infection with Ad-PKG II and stimulation with 8-pCPT-cGMP $(250 \mu \mathrm{M})$ caused 60.3, 68.1, 55.4, 65.6 and 54.1\% reductions in PCNA expression in A549, HepG2, OS-RC-2, SW480 and U251 cells, respectively, compared with the Ad-LacZ + EGF group ( $\mathrm{P}<0.05$; Fig. 2A-F). These observations suggested that PKG II may suppress the processes of DNA replication in various types of tumor cell lines.

PKG II inhibits EGF induced-migration in cancer cells. Cancer cells were infected with Ad-LacZ or Ad-PKG II, treated with 8-pCPT-cGMP and EGF, and cell migration was assessed using a Transwell migration assay. The results demonstrated that the numbers of migrated cells were increased following EGF treatment $(100 \mathrm{ng} / \mathrm{ml})$ for $12 \mathrm{~h}$, indicating that EGF enhanced the migratory activity of cancer cells $(\mathrm{P}<0.05$; Fig. $3 \mathrm{~A}$ and B). Following transfection with Ad-PKG II and stimulation with 8-pCPT-cGMP, the numbers of migrated cells were reduced by $61.5,83.2,55.9,54.2$ and $50.1 \%$ in A549, HepG2, OS-RC-2, SW480 and U251 cells, respectively, compared with

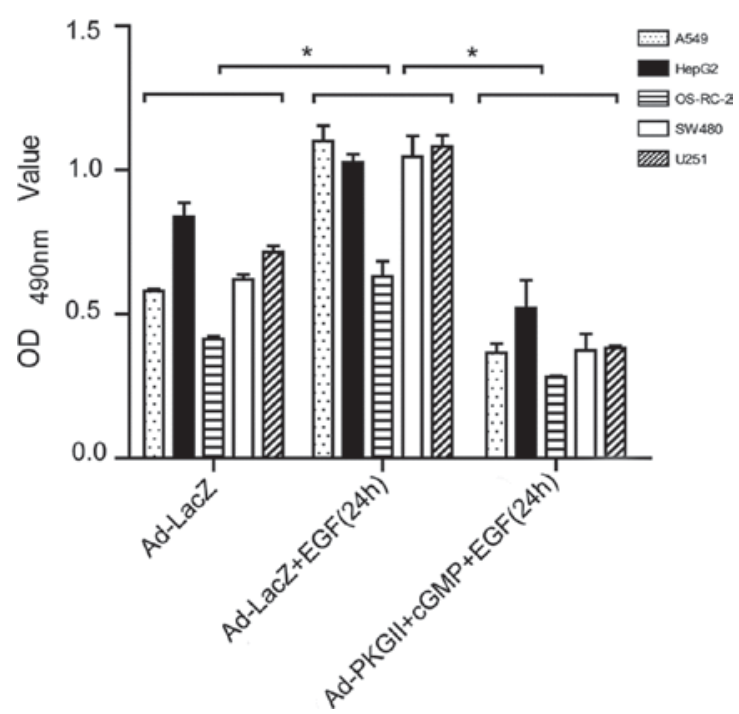

Figure 1. Results of the CCK-8 assay. Human A549 lung, HepG2 hepatic, OS-RC-2 renal, SW480 colon cancer and U251 glioma cells were infected with Ad-LacZ or Ad-PKG II, serum-starved for $12 \mathrm{~h}$, then stimulated with 8-pCPT-cGMP $(250 \mu \mathrm{M})$ for $1 \mathrm{~h}$, and subsequently treated with EGF $(100 \mathrm{ng} / \mathrm{ml})$ for $24 \mathrm{~h}$. Cell proliferation was examined using a CCK-8 assay and the OD value of the samples at $490 \mathrm{~nm}$ was determined. Data are presented as the mean \pm standard deviation of 3 independent experiments. ${ }^{*} \mathrm{P}<0.05$ comparison between groups as indicated by lines. CCK, Cell Counting kit; Ad-LacZ, adenoviral vector containing the $\beta$-galactosidase gene; Ad-PKG II, adenoviral vector containing the PKG II gene; PKG II, cGMP-dependent protein kinase type II; 8-pCPT-cGMP, 8-(4-chlorophenylthio)-cGMP; cGMP, cyclic guanosine monophosphate; EGF, epidermal growth factor; OD, optical density.

the Ad-LacZ + cGMP + EGF group (P<0.05; Fig. 3A and B). These results suggested that PKG II may inhibit the enhancing effects of EGF stimulation on cancer cell migration in vitro.

PKG II inhibits the activation of Racl. Small G protein Rac1 is the main member of the Rho family of guanosine-5'-triphosphatases (GTPases), and serves a critical role in cell migration (16). Rac1 exists in 2 forms in cells: The GTP-bound active form and the guanosine diphosphate-bound inactive form. Once Rac1 is in its GTP-bound form, it can bind and activate Raf-1 and initiate the activating cascade of Ser/Thr protein kinases in the signaling pathway $(17,18)$. To investigate whether the inhibitory effect of PKG II on cancer cell migration may be associated with the activation of Rac1, a pull-down assay was used to isolate and detect activated Rac1. The present results demonstrated that EGF stimulation resulted in the marked increase of active Rac1; conversely, PKG II overexpression was identified to efficiently inhibit the activation of Rac1 in various types of cancer cells (Fig. 4).

PKG II inhibits the EGF-induced expression of MMP2 and $M M P 7$. MMPs serve an important role in tissue remodeling, which has been associated with pathological processes, including cancer cell metastasis (19). MMP2 and MMP7 have been suggested to be critical for metastasis (20). In order to investigate the effects of PKG II on cancer cell metastasis, the protein expression of MMP2 and MMP7 was assessed. The present results demonstrated that EGF treatment $(100 \mathrm{ng} / \mathrm{ml})$ resulted in the significant upregulation of MMP2 and MMP7 protein expression levels $(\mathrm{P}<0.05$; Fig. $5 \mathrm{~A}-\mathrm{F})$. Conversely, the 

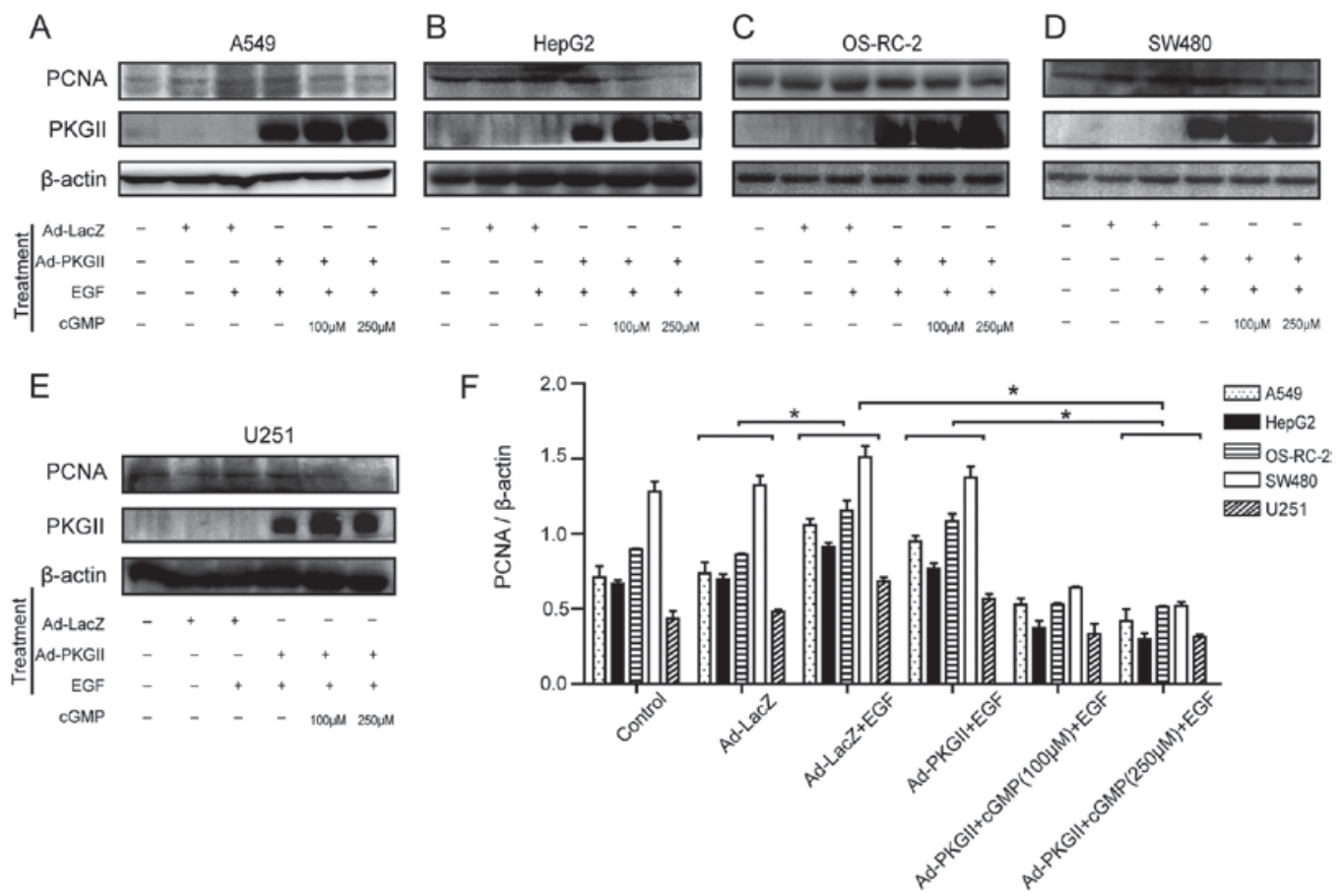

Figure 2. PKG II overexpression inhibits PCNA protein expression. Human A549 lung, HepG2 hepatic, OS-RC-2 renal, SW480 colon cancer and U251 glioma cells were infected with Ad-LacZ or Ad-PKG II for $36 \mathrm{~h}$, serum-starved for $12 \mathrm{~h}$, treated with 8-pCPT-cGMP (100 or $250 \mu \mathrm{M})$ for $1 \mathrm{~h}$, and stimulated with EGF (100 ng/ml) for $24 \mathrm{~h}$. Cells were harvested and lysed, and western blot analysis was used to assess PCNA protein expression, with $\beta$-actin as the loading control. Representative blots demonstrating PCNA protein expression in (A) A549, (B) HepG2, (C) OS-RC-2, (D) SW480 and (E) U251 cells. (F) Blots were semi-quantified using densitometric analysis. Data are presented as the mean \pm standard deviation of 3 independent experiments. " $\mathrm{P}<0.05$, comparison between groups as indicated by lines. PKG II, cyclic guanosine monophosphate-dependent protein kinase type II; PCNA, proliferating cell nuclear antigen; Ad-LacZ, adenoviral vector containing the $\beta$-galactosidase gene; Ad-PKG II, adenoviral vector containing the PKG II gene; PKG II, cGMP-dependent protein kinase type II; 8-pCPT-cGMP, 8-(4-chlorophenylthio)-cGMP; cGMP, cyclic guanosine monophosphate; EGF, epidermal growth factor.

overexpression and activation of PKG II significantly inhibited the EGF-induced increase in MMP expression $(\mathrm{P}<0.05$; Fig. 5A-F). These observations suggested that PKG II may suppress the EGF-induced migration of cancer cells in vitro.

$P K G$ II reverses the anti-apoptotic effects of EGF in cancer cells. Apoptosis is a type of programmed cell death, during which cells undergo morphological changes, including cell shrinkage, nuclear fragmentation and chromosomal DNA fragmentation (21). TUNEL is a method for detecting DNA fragmentation by labeling the terminal ends of nucleic acids; in the present study, apoptotic cells were stained dark brown. EGF treatment was demonstrated to reduce the apoptosis of A549 cells by $85.4 \%$, of HepG 2 cells by $80.6 \%$, of OS-RC-2 cells by $49.0 \%$, of SW 480 cells by $58.6 \%$, and of U251 cells by $46.9 \%$ ( $\mathrm{P}<0.05$; Fig. 6). However, among cells transfected with Ad-PKG II and incubated with 8-pCPT-cGMP, the apoptotic cells were increased by $>2$-fold compared with EGF-stimulated cells $(\mathrm{P}<0.05$; Fig. 6$)$. These results suggested that activated PKG II may counteract the anti-apoptotic effects of EGF in various types of cancer cells.

PKG II reverses EGF-induced expression of apoptosis-regulating proteins. The $\mathrm{Bcl}-2$ family contains pro-apoptotic proteins such as $\mathrm{Bax}, \mathrm{Bcl}-2$-associated death promoter and Bcl-2 homologous antagonist/killer, and anti-apoptotic proteins such as Bcl-2 and Bcl-2-like protein 2 (22). Among the various $\mathrm{Bcl}-2$ family members, the Bcl-2/Bax ratio is taken as an effective index indicating the apoptotic activities (23). In the present study, the effects of PKG II on the protein expression of Bcl-2 and Bax were investigated using western blot analysis. The present results demonstrated that across all types of cancer cells, the protein expression of $\mathrm{Bcl}-2$ was up-regulated following EGF treatment $(100 \mathrm{ng} / \mathrm{ml})$ for $12 \mathrm{~h}$; however, no marked alteration in Bax expression was detected in EGF-treated cells (Fig. 7A-E). Notably, when cells were infected with Ad-PKG II and stimulated with 8-pCPT-cGMP, EGF treatment did not appear to enhance the expression of $\mathrm{Bcl}-2$; however, the expression of Bax appeared to be increased compared with the Ad-LacZ group (Fig. 7A-E). These results indicated that PKG II suppressed the expression of the anti-apoptotic $\mathrm{Bcl}-2$ and stimulated the expression of pro-apoptotic Bax, thus causing a significant decrease in the $\mathrm{Bcl}-2 / \mathrm{Bax}$ ratio $(\mathrm{P}<0.05 ;$ Fig. $7 \mathrm{~F})$.

\section{Discussion}

cGMP-dependent signaling pathways have been reported to participate in the biological functions of tumor cells (4), and the roles of PKG I in tumorigenesis have been investigated, thus identifying PKG I as a tumor suppressor (24-26). Previous studies have suggested that PKG II may also exert inhibitory effects on the development of some tumor types $(5,27)$; however, the detailed effects of PKG II on the biological activity of cancer cells have yet to be elucidated. In the present study, the putative antitumor properties of PKG II were investigated in various types of cancer cells.

In a previous study, the expression and activity of PKG II were identified to be downregulated in cancer cell lines compared 
A

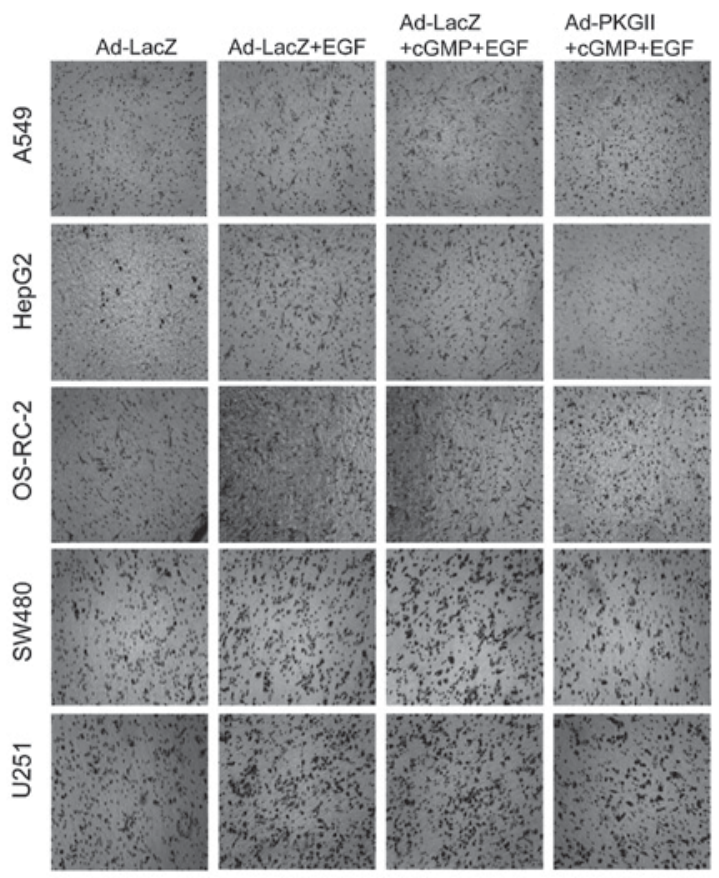

B

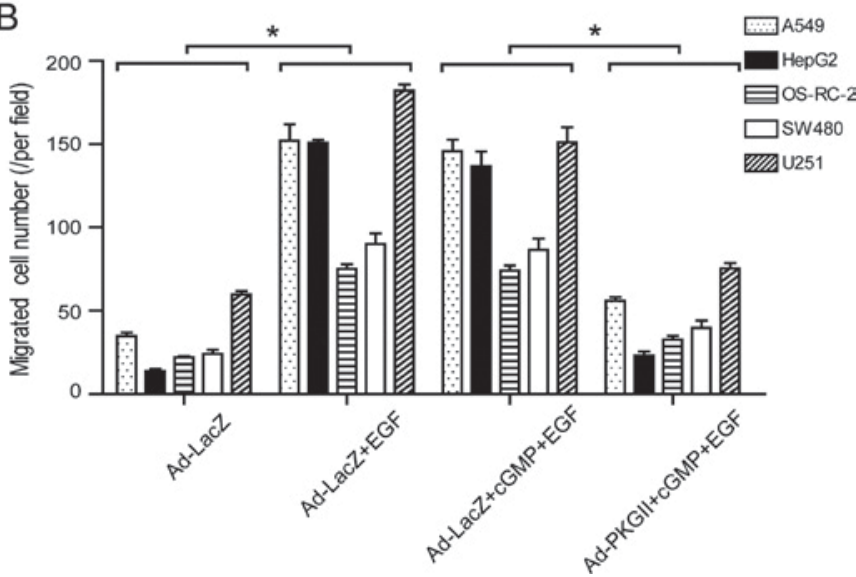

Figure 3. PKG II overexpression inhibits cancer cell migration. The migratory capabilities of human A549 lung, HepG2 hepatic, OS-RC-2 renal, SW480 colon cancer and U251 glioma cells were examined using a Transwell assay. Cells were infected with Ad-LacZ or Ad-PKG II for $36 \mathrm{~h}$, serum-starved overnight, stimulated with 8-pCPT-cGMP $(250 \mu \mathrm{M})$ and EGF $(100 \mathrm{ng} / \mathrm{ml})$, and cell migration was analyzed after $12 \mathrm{~h}$. (A) Representative photomicrographs of migrated cells following Giemsa staining (magnification, 50x). (B) The number of migrated cells in the various treatment groups. Data are presented as the mean \pm standard deviation of 3 independent experiments. ${ }^{*} \mathrm{P}<0.05$, comparison between groups as indicated by lines. PKG II, cGMP-dependent protein kinase type II; Ad-LacZ, adenoviral vector containing the $\beta$-galactosidase gene; Ad-PKG II, adenoviral vector containing the PKG II gene; 8-pCPT-cGMP, 8-(4-chlorophenylthio)-cGMP; cGMP, cyclic guanosine monophosphate; EGF, epidermal growth factor.

with in normal cells (10). Therefore, in the present study, cancer cells were infected with a PKG II-encoding adenoviral vector, in order to increase the protein expression of PKG II; subsequently, its roles in tumorigenesis were investigated. In the present study, various human cancer cell lines, including A549 lung, HepG2 hepatic, OS-RC-2 renal, SW480 colon cancer and U251 glioma cell lines, were infected with Ad-PKG II to induce PKG II overexpression. Western blot analysis demonstrated that PKG II expression was significantly up-regulated in Ad-PKG II-infected cells compared with in control cells, and it was maintained at a high level for $>96 \mathrm{~h}$ (data not shown).
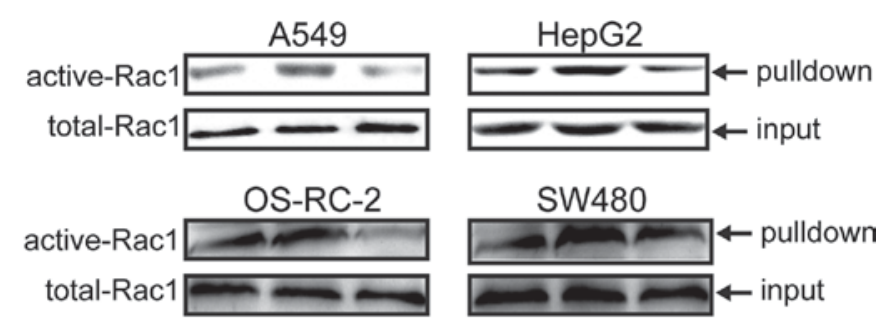

U251
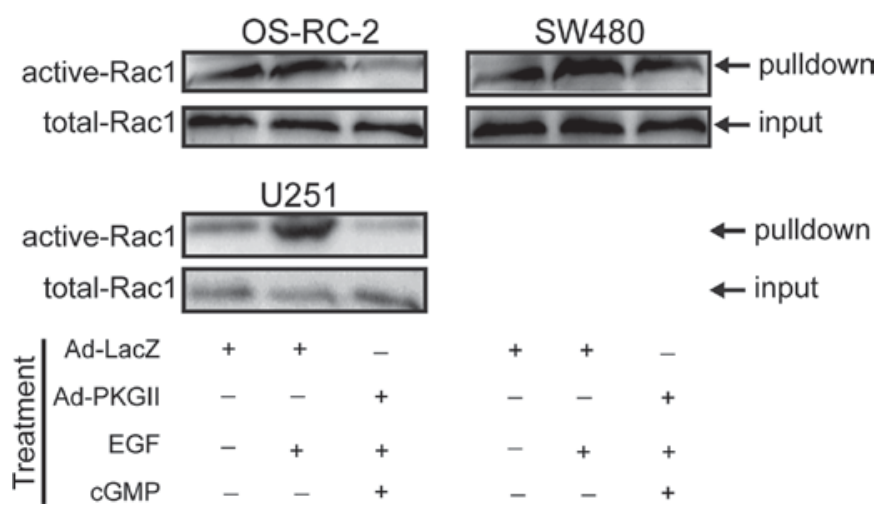

Figure 4. PKG II overexpression inhibits Rac1 activation. Activated Rac1 was detected in human A549 lung, HepG2 hepatic, OS-RC-2 renal, SW480 colon cancer and U251 glioma cells using a pull-down assay. Cell lysates were prepared and incubated with a glutathione-S-transferase-Rac- and Cdc42-regulated p21-activated kinase 1-p21 binding domain fusion protein bound to glutathione-agarose beads. Binding complexes were isolated and detected using western blotting with anti-Racl antibodies. Representative blots of 3 independent experiments are included. PKG II, cGMP-dependent protein kinase type II; Rac, Ras-related C3 botulinum toxin substrate; cGMP, cyclic guanosine monophosphate; Ad-LacZ, adenoviral vector containing the $\beta$-galactosidase gene; Ad-PKG II, adenoviral vector containing the PKG II gene; EGF, epidermal growth factor.

A CCK8 assay was used to investigate the effects of PKG II on the proliferative activity of various types of cancer cells. The present results demonstrated that cellular proliferation was significantly enhanced following EGF treatment; however, the stimulating effects of EGF were eliminated following PKG II overexpression and activation with 8-pCPT-cGMP. The CCK8 assay does not distinguish between the inhibition of proliferation and the induction of apoptosis as the mechanism underlying the decrease in live cell numbers. Therefore, the anti-proliferative effects of PKG II were further examined.

PCNA is a DNA clamp which acts as a processivity factor for DNA polymerase $\delta$ in eukaryotic cells, and is required for DNA replication (28). Antibodies against PCNA have been used for tumor grading, and they also have a diagnostic and prognostic value (29). Therefore, the expression of PCNA, as a marker of cancer cell proliferation, was detected, and the results demonstrated that PKG II inhibited the EGF-induced up-regulation of PCNA expression across all 5 cancer cell lines. These results indicated that PKG II overexpression and activation inhibited the proliferation of cancer cells in vitro.

The pro-apoptotic effects of PKG II were also examined using a TUNEL assay. In accordance with our previous results in gastric and breast cancer cells $(8,30)$, EGF stimulation was identified to suppress the apoptosis of A549, HepG2, OS-RC-2, SW480 and U251 cancer cells, whereas PKG II could reverse the anti-apoptotic effects of EGF. In order to further investigate the implication of PKG II in cancer cell apoptosis, its effects on the expression of apoptosis-associated proteins were also examined. The present results demonstrated that PKG II down-regulated the expression of the anti-apoptotic protein $\mathrm{Bcl}-2$, whereas it enhanced the expression of the pro-apoptotic protein Bax. 
A

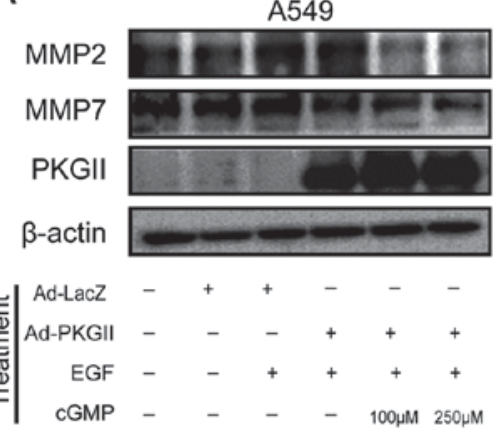

D

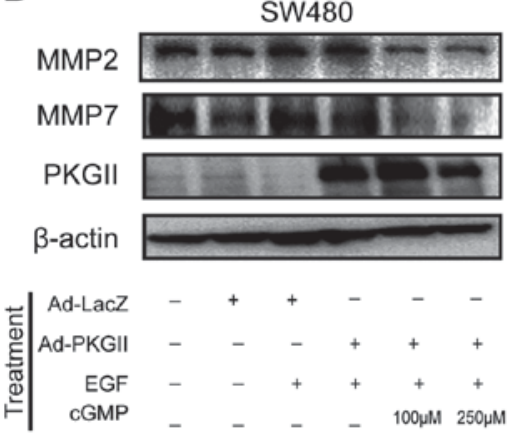

B

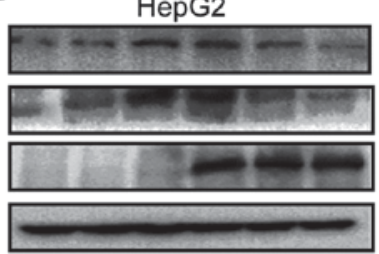

$\mathrm{E}$

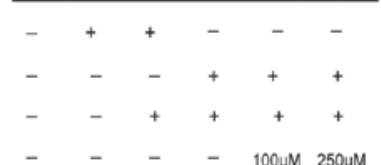

OS-RC-2

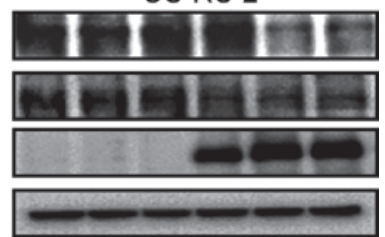

U251

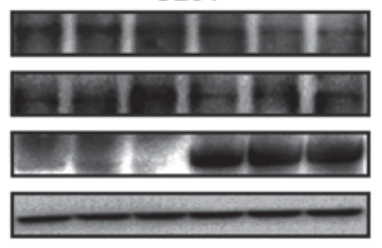

F
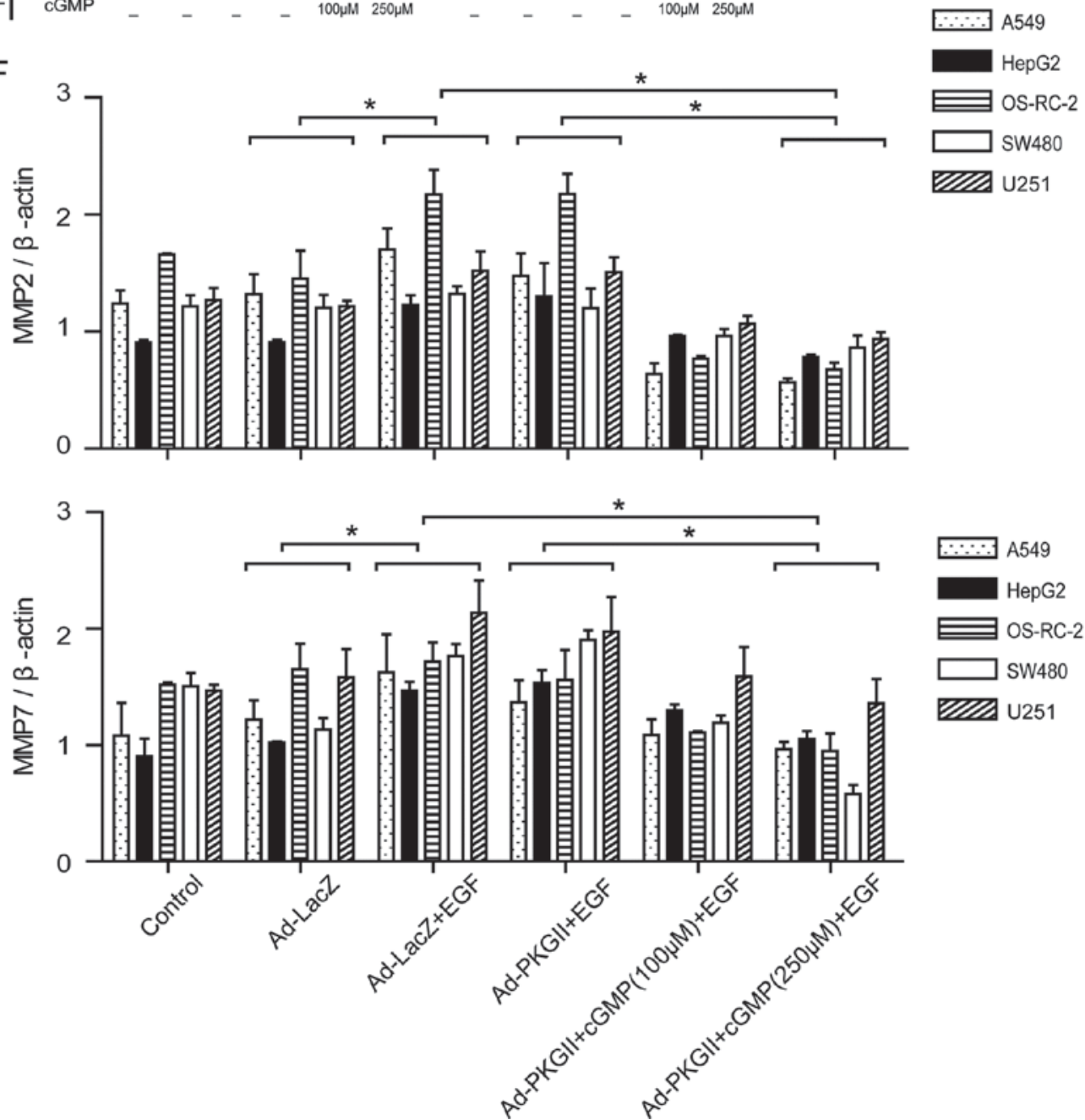

Figure 5. PKG II overexpression inhibits MMP2 and MMP7 expression. Human A549 lung, HepG2 hepatic, OS-RC-2 renal, SW480 colon cancer and U251 glioma cells were treated with Ad-LacZ or Ad-PKG II and stimulated with EGF and 8-pCPT-cGMP. Representative blots demonstrating MMP protein expression in (A) A549, (B) HepG2, (C) OS-RC-2, (D) SW480 and (E) U251 cells. (F) Blots were semi-quantified using densitometric analysis. Data are expressed as the mean \pm standard deviation of 3 independent experiments. ${ }^{*} \mathrm{P}<0.05$, comparison between groups as indicated by lines. PKG II, cGMP-dependent protein kinase type II; MMP, matrix metalloproteinase; Ad-LacZ, adenoviral vector containing the $\beta$-galactosidase gene; Ad-PKG II, adenoviral vector containing the PKG II gene; EGF, epidermal growth factor; 8-pCPT-cGMP, 8-(4-chlorophenylthio)-cGMP; cGMP, cyclic guanosine monophosphate. 
A
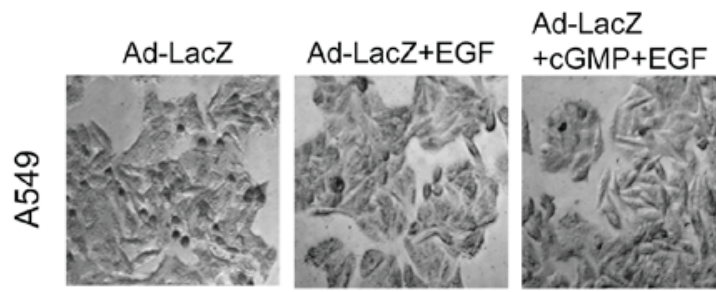

Ad-PKGII
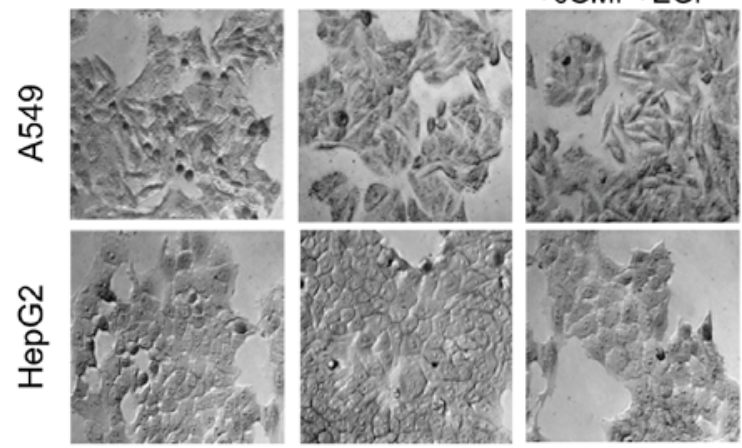

$+C G M P+E G F$
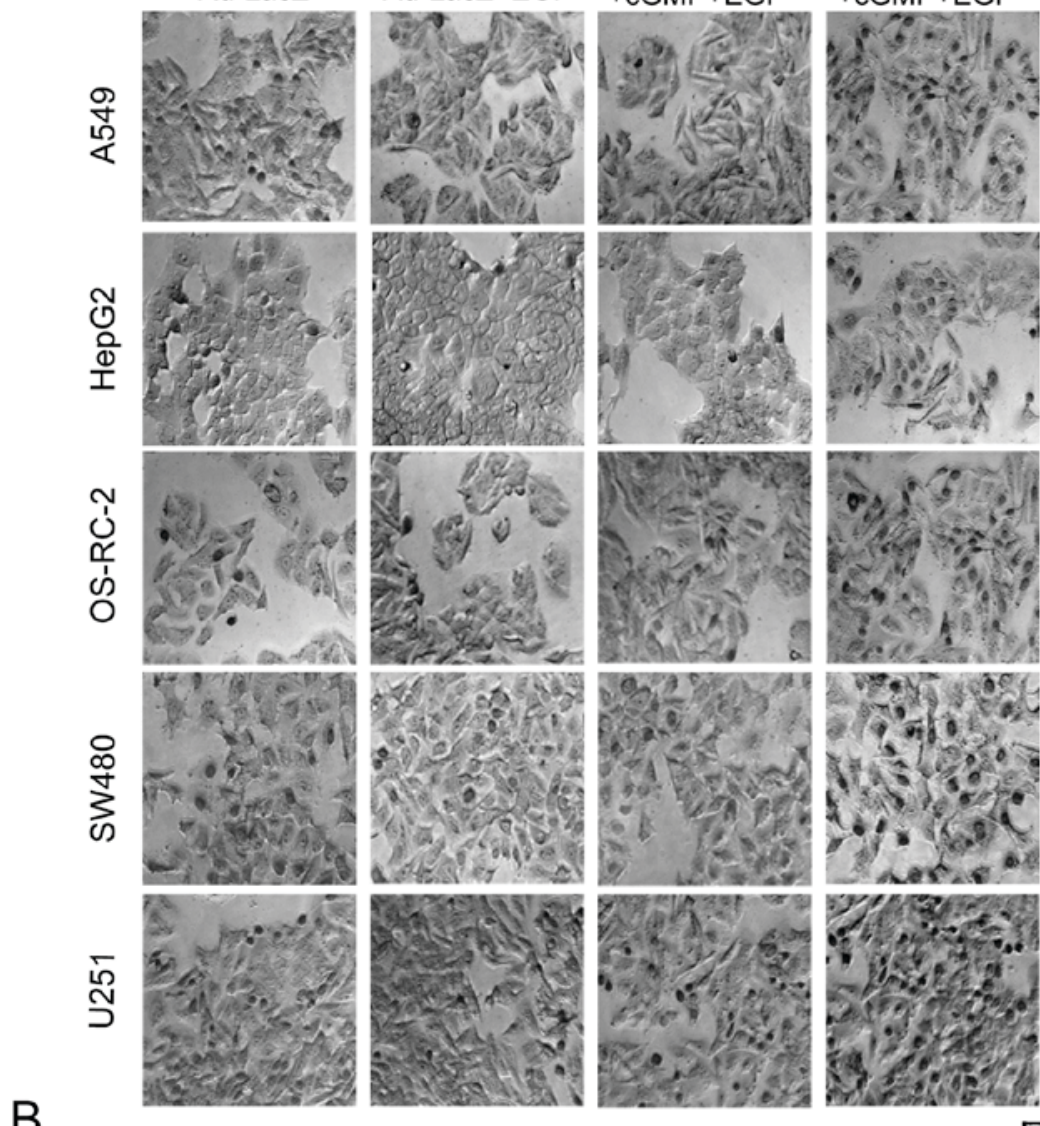

B
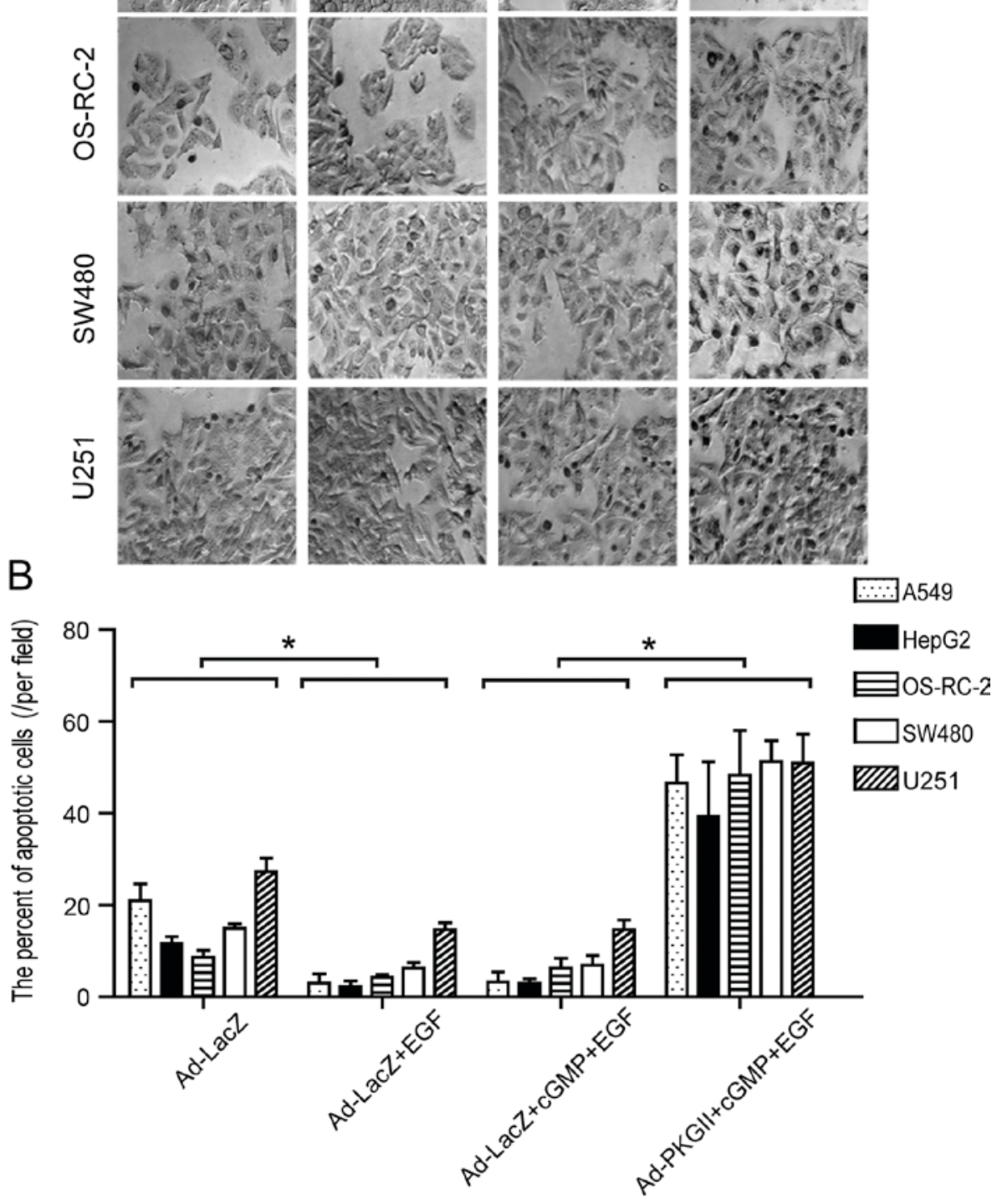

Figure 6. PKG II overexpression counteracts the anti-apoptotic effects of EGF. A terminal deoxynucleotidyl transferase 2'-deoxyuridine, 5'-triphosphate nick-end labeling assay was performed to detect apoptotic cells among human A549 lung, HepG2 hepatic, OS-RC-2 renal, SW480 colon cancer and U251 glioma cells. (A) Representative photomicrographs of apoptotic cells under x200 magnification. (B) The percentage of apoptotic cells/field of view in the various treatment groups. Data are expressed as the mean \pm standard deviation of 3 independent experiments. ${ }^{*} \mathrm{P}<0.05$, comparison between groups as indicated by lines. PKG II, cGMP-dependent protein kinase type II; EGF, epidermal growth factor; Ad-LacZ, adenoviral vector containing the $\beta$-galactosidase gene; Ad-PKG II, adenoviral vector containing the PKG II gene; cGMP, cyclic guanosine monophosphate.

These results suggested that PKG II overexpression may inhibit the proliferation and also induce the apoptosis of various types of cancer cells in vitro. These results are in accordance with the results of a previous study in gastric cancer cells (30). In combination with the previous results, it may be hypothesized that the effects of PKG II on the proliferation and apoptosis of cancer cells are associated with the inhibition of EGFR tyrosine phosphorylation/activation and EGF/EGFR-mediated signal transduction, including MAPK/ERK (12), MAPK/Janus kinase (8), and PI3K/Akt-mediated signaling (30).

Metastasis is among the key causes of cancer-associated mortality of patients. Cell migration is closely associated 

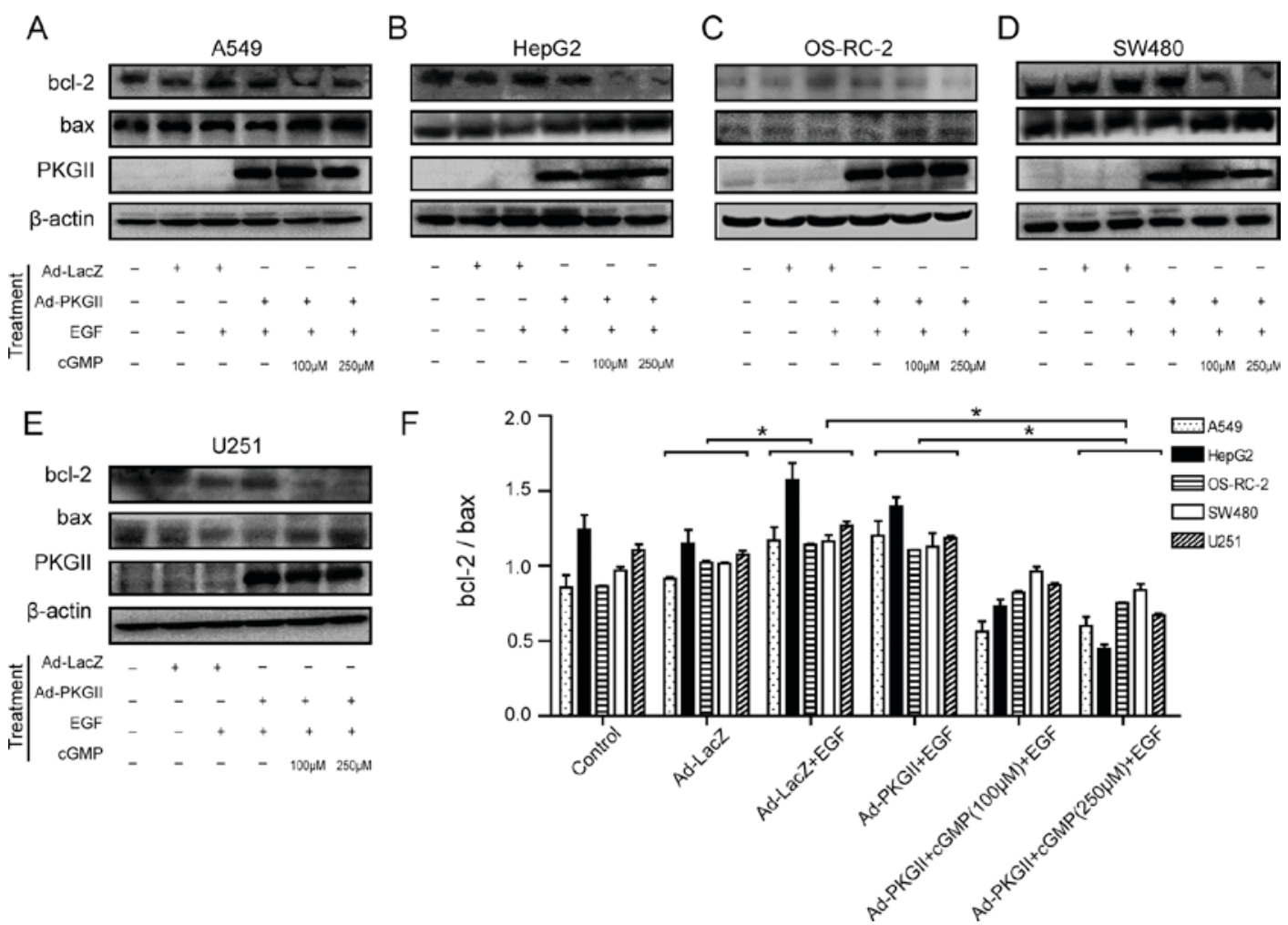

Figure 7. PKG II overexpression decreases the Bcl-2/Bax ratio. Human A549 lung, HepG2 hepatic, OS-RC-2 renal, SW480 colon cancer and U251 glioma cells were treated with Ad-LacZ or Ad-PKG II and stimulated with EGF and 8-pCPT-cGMP. Representative blots demonstrating Bcl-2 and Bax protein expression in (A) A549, (B) HepG2, (C) OS-RC-2, (D) SW480 and (E) U251 cells. (F) Blots were semi-quantified using densitometric analysis and the Bcl-2/Bax ratio was calculated. Data are expressed as the mean \pm standard deviation of 3 independent experiments. ${ }^{*} \mathrm{P}<0.05$, comparison between groups as indicated by lines. PKG II, cGMP-dependent protein kinase type II; Bcl, B-cell lymphoma; Bax, Bcl-2-associated X protein; Ad-LacZ, adenoviral vector containing the $\beta$-galactosidase gene; Ad-PKG II, adenoviral vector containing the PKG II gene; EGF, epidermal growth factor; 8-pCPT-cGMP, 8-(4-chlorophenylthio)-cGMP; cGMP, cyclic guanosine monophosphate.

with cancer metastasis, and the acquisition of migratory capabilities is critical for cancer cells to reach distant organs (31). EGF has been reported to stimulate cancer cell migration (32). Our previous study indicated that PKG II could inhibit the migration of gastric cancer cells, via blocking EGF/EGFR triggered-PLC $\gamma 1-$ and MAPK/ERK-mediated pathways (11). To investigate the putative inhibitory effects of PKG II on the migratory capabilities of various types of cancer cells, a Transwell migration assay was used. The present results indicated that activated PKG II inhibited the EGF-stimulated migration of A549, HepG2, OS-RC-2, SW480 and U251 cells in vitro. In addition, the effects of PKG II on invasion-associated proteins were also examined. MMPs are major proteolytic enzymes and can degrade almost all protein components of the extracellular matrix (ECM), thus destroying the tissue barriers to tumor cell invasion, and serve a key role in cancer invasion and metastasis (33). The present results demonstrated that following PKG II overexpression, the expression of MMP2 and MMP7 was downregulated, thus suggesting that PKG II may inhibit the degradation of ECM protein components and suppress the metastatic potential of cancer cells.

In conclusion, the present study demonstrated that PKG II overexpression inhibited the EGF-induced potentiation of the migratory and proliferative capabilities of cancer cells. In addition, it counteracted the anti-apoptotic effects of EGF stimulation in several types of cancer cells, including lung, colon, liver, kidney cancer and glioma. A preliminary investigation of the molecular mechanisms that were involved indicated that PKG II overexpression resulted in the decreased expression of the proliferation index PCNA,themetastasis-associatedproteinsMMP2andMMP7, and the anti-apoptotic protein Bcl-2; conversely, it up-regulated the expression of the pro-apoptotic protein Bax in cancer cells. These results suggested that PKG II may exert inhibitory effects on the growth and metastasis in various types of cancer cells derived from several tissues, and suggested a role for endogenous PKG II as a potential tumor suppressor. Our findings will provide theoretical support for the potential treatment of cancer patients with big molecular inhibitors, especially protein molecules. Furthermore, since PKG II is an endogenous protein kinase, its potential application in treatment of cancers can avoid some side-effect such as immunologic rejection and poisonous effects. This will suggest new strategy for cancer treatment.

\section{Acknowledgements}

The authors would like to thank Dr. Gerry Boss and Dr. Renate Pilz (University of California, San Diego, CA, USA) for the kind gifts of the adenoviral constructs used in the present study. The present study was supported by the National Natural Science Foundation of China (grant nos. 81272755, 81201959 and 81001100), the Natural Science Foundation Project 
of Jiangsu Province (grant no. 12KJB310001), the China Postdoctoral Science Foundation (grant no. 2014M561599), the Postdoctoral Research Funding Plan in Jiangsu Province (grant no. 1401144C) and the Specialized Research Fund for Senior Personnel Program of Jiangsu University (grant no. 11JDG114).

\section{References}

1. Hanahan D and Weinberg RA: Hallmarks of cancer: The next generation. Cell 144: 646-674, 2011.

2. Vaandrager AB, Edixhoven M, Bot AG, Kroos MA, Jarchau T, Lohmann S, Genieser HG and de Jonge HR: Endogenous type II cGMP-dependent protein kinase exists as a dimer in membranes and can Be functionally distinguished from the type I isoforms. J Biol Chem 272: 11816-11823, 1997.

3. Gamm DM, Francis SH, Angelotti TP, Corbin JD and Uhler MD: The type II isoform of cGMP-dependent protein kinase is dimeric and possesses regulatory and catalytic properties distinct from the type I isoforms. J Biol Chem 270: 27380-27388, 1995.

4. Hofmann F: The biology of cyclic GMP-dependent protein kinases. J Biol Chem 280: 1-4, 2005.

5. Cook AL and Haynes JM: Protein kinase G II-mediated proliferative effects in human cultured prostatic stromal cells. Cell Signal 16: 253-261, 2004.

6. Swartling FJ, Ferletta M, Kastemar M, Weiss WA and Westermark B: Cyclic GMP-dependent protein kinase II inhibits cell proliferation, Sox9 expression and Akt phosphorylation in human glioma cell lines. Oncogene 28: 3121-3131, 2009

7. Wang R, Kwon IK, Thangaraju M, Singh N, Liu K, Jay P, Hofmann F, Ganapathy V and Browning DD: Type 2 cGMP-dependent protein kinase regulates proliferation and differentiation in the colonic mucosa. Am J Physiol Gastrointest Liver Physiol 303: G209-G219, 2012.

8. Lan T, Chen Y, Sang J, Wu Y, Wang Y, Jiang L and Tao Y: Type II cGMP-dependent protein kinase inhibits EGF-induced MAPK/JNK signal transduction in breast cancer cells. Oncol Rep 27: 2039-2044, 2012.

9. Fallahian F, Karami-Tehrani F, Salami S and Aghaei M: Cyclic GMP induced apoptosis via protein kinase G in oestrogen receptor-positive and -negative breast cancer cell lines. FEBS J 278: 3360-3369, 2011.

10. Yang SQ, Chen YC, Wang Y and Tao Y: Expression of cGMP dependent protein kinase II in cancer cell lines was obviously decreased.J Jiangsu Univ (Medicine Ed) 18: 1-5, 2008 (In Chinese).

11. Jiang L, Lan T, Chen Y, Sang J, Li Y, Wu M, Tao Y, Wang Y, Qian $\mathrm{H}$ and Gu L: PKG II inhibits EGF/EGFR-induced migration of gastric cancer cells. PLoS One 8: e61674, 2013.

12. Wu Y, Chen Y, Qu R, Lan T and Sang J: Type II cGMP-dependent protein kinase inhibits EGF-triggered signal transduction of the MAPK/ERK-mediated pathway in gastric cancer cells. Oncol Rep 27: 553-558, 2012.

13. Chen YC, Ren F, Sang JR, Tao Y and Xu WR: Type II cGMP-dependent protein kinase inhibits proliferation of the gastric cancer cell line BGC-823. Mol Med Rep 3: 361-366, 2010.

14. Chen WY and Abatangelo G: Functions of hyaluronan in wound repair. Wound Repair Regen 7: 79-89, 1999.

15. Guzińska-Ustymowicz K, Pryczynicz A, Kemona A and Czyzewska J: Correlation between proliferation markers: PCNA, $\mathrm{Ki}-67, \mathrm{MCM}-2$ and antiapoptotic protein $\mathrm{Bcl}-2$ in colorectal cancer. Anticancer Res 29: 3049-3052, 2009.

16. Pasapera AM, Plotnikov SV, Fischer RS, Case LB, Egelhoff TT and Waterman CM: Rac1-dependent phosphorylation and focal adhesion recruitment of myosin IIA regulates migration and mechanosensing. Curr Biol 25: 175-186, 2015.
17. Seinen ML, van Nieuw Amerongen GP, de Boer NK and van Bodegraven AA: Rac attack: Modulation of the small GTPase rac in inflammatory bowel disease and thiopurine therapy. Mol Diagn Ther 20: 551-557, 2016.

18. Marshall M: Interactions between Ras and Raf: Key regulatory proteins in cellular transformation. Mol Reprod Dev 42: 493-499, 1995.

19. Brown GT and Murray GI: Current mechanistic insights into the roles of matrix metalloproteinases in tumour invasion and metastasis. J Pathol 237: 273-281, 2015.

20. Chou YC, Chang MY, Wang MJ, Yu FS, Liu HC, Harnod T, Hung $\mathrm{CH}$, Lee HT and Chung JG: PEITC inhibits human brain glioblastoma GBM 8401 cell migration and invasion through the inhibition of uPA, Rho A and Ras with inhibition of MMP-2, -7 and -9 gene expression. Oncol Rep 34: 2489-2496, 2015.

21. Ouyang L, Shi Z, Zhao S, Wang FT, Zhou TT, Liu B and Bao JK: Programmed cell death pathways in cancer: A review of apoptosis, autophagy and programmed necrosis. Cell Prolif 45: 487-498, 2012.

22. Zheng JH, Viacava Follis A, Kriwacki RW and Moldoveanu T: Discoveries and controversies in BCL-2 protein-mediated apoptosis. FEBS J 283: 2690-2700, 2016.

23. Mohammadi A, Yaghoobi MM, GholamhoseynianNajar A, Kalantari-Khandani B, Sharifi H and Saravani M: HSP90 inhibitor enhances anti-proliferative and apoptotic effects of celecoxib on HT-29 colorectal cancer cells via increasing BAX/BCL-2 ratio. Cell Mol Biol (Noisy-le-grand) 62: 62-67, 2016.

24. Karakhanova S, Golovastova M, Philippov PP, Werner J and Bazhin AV: Interlude of cGMP and cGMP/protein kinase $\mathrm{G}$ type 1 in pancreatic adenocarcinoma cells. Pancreas 43: 784-794, 2014.

25. Wong JC, Bathina M and Fiscus RR: Cyclic GMP/protein kinase G type-Ialpha (PKG-Ialpha) signaling pathway promotes CREB phosphorylation and maintains higher c-IAP1, livin, survivin and Mcl-1 expression and the inhibition of PKG-Ialpha kinase activity synergizes with cisplatin in non-small cell lung cancer cells. J Cell Biochem 113: 3587-3598, 2012.

26. Karami-Tehrani F, Fallahian F and Atri M: Expression of cGMP-dependent protein kinase, PKGIalpha, PKGIbeta and PKGII in malignant and benign breast tumors. Tumour biology 33: 1927-1932, 2012.

27. Chikuda H, Kugimiya F, Hoshi K, Ikeda T, Ogasawara T, Shimoaka T, Kawano H, Kamekura S, Tsuchida A, Yokoi N, et al: Cyclic GMP-dependent protein kinase II is a molecular switch from proliferation to hypertrophic differentiation of chondrocytes. Genes Dev 18: 2418-2429, 2004.

28. Strzalka W and Ziemienowicz A: Proliferating cell nuclear antigen (PCNA): A key factor in DNA replication and cell cycle regulation. Ann Bot 107: 1127-1140, 2011.

29. Goel MM and Mehrotra A: Immunohistochemical expression of MIB-1 and PCNA in precancerous and cancerous lesions of uterine cervix. Indian J Cancer 50: 200-205, 2013

30. Wu M, Chen Y, Jiang L, Li Y, Lan T, Wang Y and Qian H: Type II cGMP-dependent protein kinase inhibits epidermal growth factor-induced phosphatidylinositol-3-kinase/Akt signal transduction in gastric cancer cells. Oncol Lett 6: 1723-1728, 2013.

31. Tian T, Li X, Hua Z, Ma J, Liu Z, Chen H and Cui Z: S100A1 promotes cell proliferation and migration and is associated with lymph node metastasisin ovarian cancer. Discov Med 23: 235-245, 2017.

32. Navarini NF, Araùjo VC, Brown AL, Passador-Santos F, Souza IF, Napimoga MH, Araújo NS and Martinez EF: The EGF signaling pathway influences cell migration and the secretion of metalloproteinases by myoepithelial cells in pleomorphic adenoma. Tumour Biol 36: 205-211, 2015.

33. Liu Q, Yang P, Tu K, Zhang H, Zheng X, Yao Y and Liu Q: TPX2 knockdown suppressed hepatocellular carcinoma cell invasion via inactivating AKT signaling and inhibiting MMP2 and MMP9 expression. Chin J Cancer Res 26: 410-417, 2014. 